\title{
Aortic floating thrombus detected by computed tomography angiography incidentally: Five cases and a literature review
}

\author{
Shuyi Yang, MS, ${ }^{\text {a }}$ Jie Yu, MD, ${ }^{a}$ Wenjuan Zeng, BS, ${ }^{\mathrm{b}}$ Liang Yang, MS, ${ }^{\mathrm{a}}$ Lin Teng, MS, ${ }^{\mathrm{a}}$ Yue Cui, MD, ${ }^{\mathrm{a}}$ and
} Heshui Shi, MD

\section{ABSTRACT}

Objective: To analyze the findings of aortic floating thrombus (AFT) on computed tomography angiography (CTA) for a definitive, timely diagnosis and to select a reasonable management course to improve prognosis.

Method: We retrospectively analyzed imaging findings of 5 patients with AFT detected by CTA, including location, morphology, size, involved aortic segment, concomitant embolism, stent, and dynamic changes during the follow-up.

Results: Seven lesions were detected in the initial CTA studies of the 5 patients: 5 aortic intraluminal floating thrombi (3 patients) and 2 aortic in-stents floating thrombi (ASFTs; 2 patients). One aortic intraluminal floating thrombus was located in the right anterior wall of the ascending aorta and 2 in the aortic isthmus. Interval increasing in size of the splenic embolism and a new renal segmental artery embolism were noted in 1 patient after 7 days anticoagulation therapy. One ASFT was located in the original narrowing part of the aortic stent and another in the overlap of the stents. During the follow-up, some lesions disappeared, whereas the morphology and size varied in others. Four new ASFTs occurred. All the lesions were attached to the focal thickened inner walls of the stents with the free-floating portions along the direction of blood flow.

Conclusions: AFT is a rare, life-threatening disease. Abnormal coagulation function, aortic disease, and history of aortic stent implantation are the potential predictors for AFT. CTA scanning can depict the lesions clearly and evaluate curative efficacy. The therapeutic strategy should be based on the etiology and the patient's physical condition, whereas the preferred treatment is conservative medication. (J Thorac Cardiovasc Surg 2017;153:791-803)

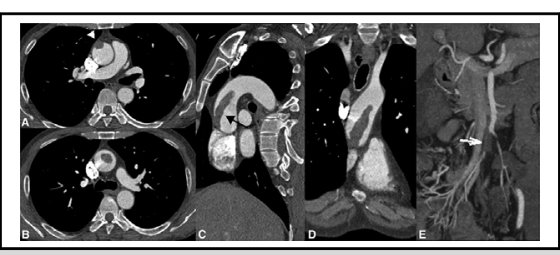

Computed tomography angiography showed a large, cylinder-shaped lesion attached to the eccentric thickened wall of aorta.

Central Message

We aimed to analyze the findings of aortic floating thrombus on computed tomography angiography for a definitive, timely diagnosis and to consider management options to improve patient prognosis.

\section{Perspective}

Abnormal coagulation function, aortic disease, and history of aortic stent implantation are potential predictors of aortic floating thrombus. Unexplained chest pain and abdominal pain should alert clinicians, whereas computed tomography angiography can depict the lesions clearly. Their management varies in levels of invasiveness; conservative treatment (medication) is recommended as a first choice.

See Editorial Commentary page 804.
Aortic mural thrombus (AMT) mainly is secondary to severe aortic atherosclerosis, aneurysm, aortic dissection, and aortitis; commonly is located in the lower abdominal aorta; and is attached closely to the inner wall of the aorta. The inner portion of the thrombus attaches to the wall with a free-floating component that is located in the thoracic aorta,

\footnotetext{
From the Departments of a Radiology and ${ }^{\mathrm{b}}$ Clinical Laboratory, Union Hospital, Tongji Medical College, Huazhong University of Science and Technology, Wuhan, China.

Supported by the National Natural Science Foundation of China Grant No. 81271570. $\mathrm{S}$. Yang and J. Yu contributed equally to this work.

Received for publication Sept 19, 2016; revisions received Nov 8, 2016; accepted for publication Dec 5, 2016; available ahead of print Jan 11, 2017.

Address for reprints: Heshui Shi, MD, Department of Radiology, Union Hospital, Tongji Medical College, Huazhong University of Science and Technology, 1277 JieFang Ave, Wuhan 430022, China (E-mail: heshuishi@hotmail.com). $0022-5223 / \$ 36.00$

Copyright (C) 2016 by The American Association for Thoracic Surgery http://dx.doi.org/10.1016/j.jtcvs.2016.12.015
}

or an aortic stent occasionally is detected by computed tomography angiography (CTA). Its etiopathogenesis remains enigmatic. We report 5 cases of aortic floating thrombi (AFTs) on CTA findings and the evolution during follow-up to alert radiologists and clinicians to provide timely and effective treatments.

\section{MATERIALS AND METHODS \\ Patients}

Clinical features and initial and follow-up CTA findings of patients with AFT from March 2010 to April 2016 in our institution were reviewed

Scanning this QR code will take you to supplemental videos for the article.

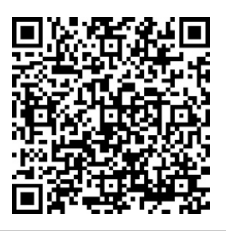



Abbreviations and Acronyms
AFT = aortic floating thrombus
$\mathrm{AMT}=$ aortic mural thrombus
ALFT $=$ aortic intraluminal floating thrombus
ASFT $=$ aortic in-stent floating thrombus
boRR $=$ break-off risk ratio
$\mathrm{CT}=$ computed tomography
CTA $=$ computed tomography angiography
SMA $=$ superior mesenteric artery
TEE $=$ transesophageal echocardiography

retrospectively. Five patients, including 4 men and 1 woman aged 18 to 73 years (median age 56 years), formed part of this review. No patients had severe aortic diseases, such as aortic atherosclerosis, aneurysm, or aortic dissection. Three patients achieved a definitive diagnosis clinically, whereas 1 patient underwent surgery (thrombectomy and ascending aorta replacement) with the pathologic result of luminal thrombus with organization. These patients all had hypercoagulable states at different levels, whereas 1 patient had a high platelet count level, which increased to $954 \times 10^{9} / \mathrm{L}\left(<300 \times 10^{9} / \mathrm{L}\right)$. Two other patients underwent aortic stent implantations previously for thoracic aorta coarctation and abdominal aortic aneurysm, respectively. The thrombi were located inside the stents and confirmed clinically. One patient had not taken anticoagulant drugs regularly after surgery. In 3 patients, the cardinal symptoms were abdominal pain/discomfort, whereas another patient experienced chest pain. All the patients achieved clinical improvement/cures after proper/appropriate treatments. Four patients were followed by CTA in our institution ( 2 cases once, 2 cases twice; interval time: 7 days-22 months; follow-up period: 14 months-65 months). Table 1 details the clinical features and followup periods of these 5 patients.

\section{Instruments, Postprocessing, and Image Analysis}

Patients underwent aortic CTA examinations with electrocardiograph gating by a multislice spiral computed tomography (CT) scanner (Somatom Definition AS+; Siemens, München, Germany) in our institution. The scanning parameters followed standard CTA techniques. Postprocessing of all the images was accomplished by Syngo.via (Siemens), including a volume-rendering technique, maximum intensity projection, and multiplanar reconstruction. Cine images with multiphase reconstruction from $0 \%$ to $90 \%$ of the cardiac cycle with the interval of $10 \%$ were obtained in 1 patient. Observation parameters included location of the AFT, morphology, size, the involved aorta, concomitant visceral or vascular embolism, stent, and the dynamic changes of these signs during the follow-up. We also defined a new parameter, called break-off risk ratio (boRR), as the length ratio of the floating portion and the attached portion (Figure 1). The analysis of CTA findings was performed independently by 2 senior radiologists with 10 years' reading experience. If disagreement occurred, the readers discussed it and reached a consensus.

\section{RESULTS}

A total of 7 AFTs were revealed by CTA in the 5 patients' initial examinations. We divided the patients into 2 groups: with or without stent implantation. There were 5 aortic intraluminal floating thrombi (ALFTs; 3 patients): 1 ALFT was located in the right anterior wall of ascending aorta, 2 in the aortic isthmus (one patient's descending aortic arch tortuous), 1 in the thoracic aorta, and 1 in the upper abdominal aorta. The morphologies of ALFT varied, such as cylinder, striped, or spindle-shaped, with distal portions free-floating (Figures 2-4). Two ALFTs bifurcated distally with small branches (Figures 3 and 4). The lengths of ALFT varied from $0.4 \mathrm{~cm}$ to $5.6 \mathrm{~cm}$ (average: $2.3 \mathrm{~cm}$ ), whereas the boRR ranged from 2.0 to 8.0. Three ALFTs protruded from the focal eccentric thickened walls of the aorta (Figures 2 and 3), 1 from the ostium of the intercostal artery with partial inserted (Figure 4), and another from the focal thickened wall of the aorta close to the ostium of the intercostal artery (Figure 4). Three ALFTs were growing along with the direction of the blood flow (Figures 2 and 3), whereas 2 others were perpendicular (Figure 4). The cine-CT clearly depicted 2 ALFT floating processes through the cardiac cycle (Videos 1 and 2). One patient presented with partial splenic infarction (Figure 3), 1 with pulmonary infarction and the line-like thrombus inside bilateral pulmonary veins (Figure 4), whereas another 2 had superior mesenteric artery (SMA) embolisms (Figure 2). Two patients' ALFTs disappeared after clinical treatments (interval time: 7 days, 21 months), one of whose original splenic infarction enlarged and a left renal segmental infarction appeared in the follow-up CTA.

There were 2 aortic in-stents floating thrombi (ASFTs) in our study (2 patients); those, respectively, were located in the original narrowing part of the thoracic aortic stent (2828C80EE; Medtronic, Minneapolis, Minn) in patient 4 (Figure 5) and the junction of aortoiliac stent body and iliac branch (body: Medtronic 2513C145EE; branch: Medtronic 1613C120EE) in patient 5 (Figure 6). The morphologies of ASFT were irregular and flaky in appearance, whereas there were multiple attached points, and the medial portions were free-floating. The proximal end of this covered thoracic aortic stent was located in the aortic arch with space to the vessel wall and was inserted partially into the proximal left subclavian artery (Figure 5). The aortoiliac stent was herringbone, of which the upper segment was tortuous with type II internal leakage (Figure 6). No peripheral embolisms were noted.

CTA was repeated twice during the follow-up (28 months, 41 months). Patient 4's lesion decreased in size, and the inner wall of stent inside left subclavian artery was thickened in the first 6 months' follow-up study, whereas the original lesion enlarged irregularly, with a new wire-shaped lesion appearing in the distal mild expanded stent in the second 14 months' follow-up study (Figure 7). Patient 5's original thrombus disappeared with a new flaky lesion abutting the overlapping portion of the stents. An additional a new wire-shaped thrombus was noted in the proximal kinking segment of the stent on the first 19-month follow-up CTA study. Two previous detected thrombi in patient 5 were 
TABLE 1. The clinical features of 5 patients with aortic floating thrombus included in our report

\begin{tabular}{|c|c|c|c|c|c|c|c|c|}
\hline Case & $\begin{array}{c}\text { Age, } \\
\mathbf{y} \\
\end{array}$ & Sex & $\begin{array}{c}\text { Main } \\
\text { complaint }\end{array}$ & $\begin{array}{c}\text { Other } \\
\text { symptoms }\end{array}$ & Clinical histories & $\begin{array}{c}\text { Physical } \\
\text { examination } \\
\text { (positive signs) } \\
\end{array}$ & $\begin{array}{c}\text { Main laboratory } \\
\text { examinations* }\end{array}$ & Therapy/prognosis \\
\hline 1 & 47 & Male & $\begin{array}{l}\text { Abdominal } \\
\text { pain }\end{array}$ & - & $\begin{array}{l}\text { Hypertension for } 7-8 \mathrm{y} \text {, } \\
\text { smoking }(6 / \mathrm{d}, 10 \mathrm{y}) \\
\text { and alcohol } \\
\text { consumption } \\
(20-30 \mathrm{~mL} / \mathrm{d}, 10 \mathrm{y})\end{array}$ & $\begin{array}{l}\text { Epigastric } \\
\text { tenderness }\end{array}$ & $\begin{array}{l}\text { D-dimer: } 0.674 \mathrm{mg} / \mathrm{L} \\
\text { FEU (normal } \\
\quad<0.5 \mathrm{mg} / \mathrm{L} \mathrm{FEU} \text { ); }\end{array}$ & $\begin{array}{l}\text { Surgery } \\
\text { (thrombectomy } \\
\text { and ascending } \\
\text { aorta replacement, } \\
\text { mural thrombosis } \\
\text { with organization)/ } \\
\text { no special symptoms }\end{array}$ \\
\hline 2 & 62 & Male & $\begin{array}{l}\text { Abdominal } \\
\text { pain }\end{array}$ & - & - & $\begin{array}{l}\text { Epigastric } \\
\text { tenderness }\end{array}$ & $\begin{array}{l}\text { LDH: } 552 \mathrm{U} / \mathrm{L} \\
\quad(109-245 \mathrm{U} / \mathrm{L}) ; \\
\text { D-dimer: } \\
1.28 \mathrm{mg} / \mathrm{L} \text { FEU } \\
(<0.5 \mathrm{mg} / \mathrm{L} \mathrm{FEU}) ; \\
\text { platelets: } 954 \times 10^{9} / \mathrm{L} \\
\left(<300 \times 10^{9} / \mathrm{L}\right) ; \\
\text { homocysteine: } \\
21.2 \mu \mathrm{mol} / \mathrm{L} \\
(\text { normal }<20 \mu \mathrm{mol} / \mathrm{L})\end{array}$ & $\begin{array}{l}\text { Anticoagulation/ } \\
\text { Lesions disappeared, } \\
\text { slight greater level } \\
\text { of platelets } \\
\left(575 \times 10^{9} / \mathrm{L}\right)\end{array}$ \\
\hline 3 & 73 & Male & $\begin{array}{l}\text { Recurring } \\
\text { chest pain }\end{array}$ & $\begin{array}{l}\text { Dizziness, } \\
\text { palpitation, } \\
\text { short of breath, } \\
\text { cough and } \\
\text { expectoration } \\
\text { with fever }\end{array}$ & $\begin{array}{c}\text { Syncope with loss of } \\
\text { consciousness in } 3 \\
\text { previous episodes }\end{array}$ & $\begin{array}{l}\text { Blood pressure: } \\
\text { 170/110 mm Hg, } \\
\text { right lower } \\
\text { pulmonary } \\
\text { moist crackles, } \\
\text { tenderness in the } \\
\text { subcostal } \\
\text { abdomen }\end{array}$ & $\begin{array}{l}\text { D-dimer: } 13.51 \mathrm{mg} / \mathrm{L} \\
\text { FEU (normal } \\
\quad<0.5 \mathrm{mg} / \mathrm{L} \mathrm{FEU} \text { ) }\end{array}$ & $\begin{array}{l}\text { Anticoagulation/ } \\
\text { previous complaints } \\
\text { partially relieved but } \\
\text { with new-onset } \\
\text { leg pain }\end{array}$ \\
\hline 4 & 18 & Male & $\begin{array}{l}\text { Aorta } \\
\text { coarctation, } \\
\text { poststent graft } \\
\text { evaluation }\end{array}$ & - & $\begin{array}{l}\text { Coarctation of } \\
\text { proximal } \\
\text { descending aorta }\end{array}$ & - & - & $\begin{array}{l}\text { Anticoagulation and } \\
\text { hypotensor regularly/ } \\
\text { lesions relapsed } \\
\text { during follow-up } \\
\text { without peripheral } \\
\text { embolism }\end{array}$ \\
\hline 5 & 56 & Female & $\begin{array}{l}\text { Abdominal } \\
\text { aortic } \\
\text { aneurysm, } \\
\text { abdominal } \\
\text { discomfort, } \\
\text { poststent } \\
\text { graft } \\
\text { evaluation }\end{array}$ & - & $\begin{array}{l}\text { Abdominal aortic } \\
\text { aneurysm }\end{array}$ & - & - & $\begin{array}{l}\text { Observation/lesions } \\
\text { relapsed without } \\
\text { peripheral embolism }\end{array}$ \\
\hline
\end{tabular}

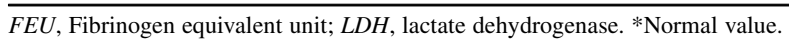

resolved; however, a new flaky thrombus developed at the junction of the stent body and branch in the second 22-month follow-up study (Figure 6). The floating portions of the ASFT were generally along with the direction of blood flow, whereas the lesions were all attached to the focal thickened inner walls of the stents. There were no new peripheral embolisms; however, in 1 patient, the stent lumen expanded in a nonuniform fashion during the follow-up (Figure 7). The details of all the patients' imaging signs are provided in Table 2 .

\section{DISCUSSION}

The Definition and Clinical Significance of AFT

AMTs can be sessile and pedunculated ${ }^{2,3}$; whereas the former is more common, the latter more easily breaks off and results in vital visceral and peripheral embolism, which should attract the attention of clinicians and radiologists. Because of the special hemodynamic features of pedunculated aortic thrombus, the term AFT has been used widely. It has been reported that the pedunculated thrombus has a greater risk of breaking off 


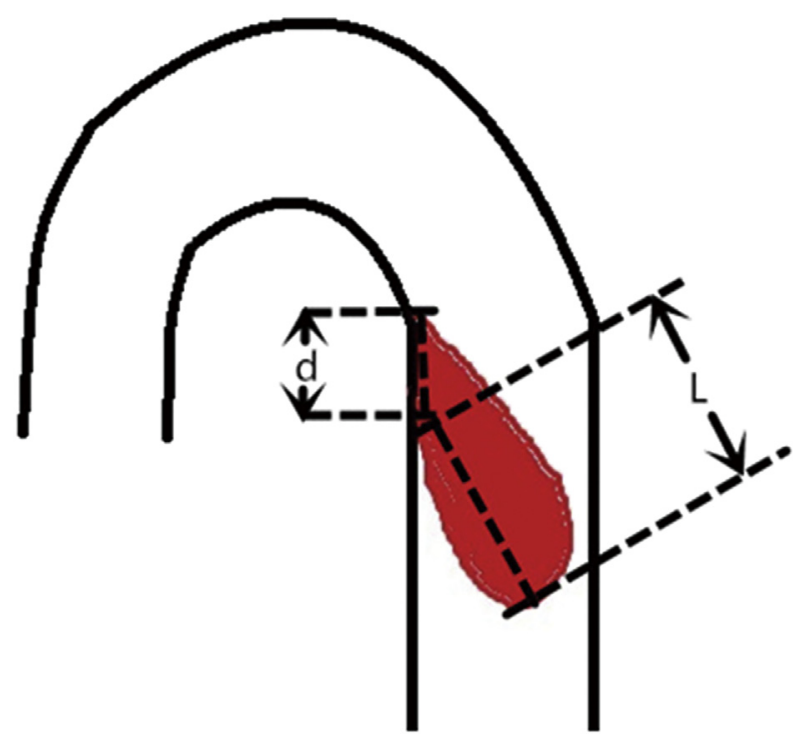

FIGURE 1. Diagram of boRR calculation, L represents the length of lesion's floating portion on the longest axis; $d$ is the length of lesion's attachment portion on the longest axis. boRR $=\mathrm{L} / \mathrm{d}$.

to produce severe peripheral embolism in contrast with the sessile one $(73 \%$ vs $12 \%))^{3}$ Arterial thromboembolism has become one of the most common diseases, with a high rate of morbidity and mortality. ${ }^{2}$ Approximately $80 \%$ to $90 \%$ of arterial emboli originate from heart diseases (eg, myocardial infarction, rheumatic heart disease, atrial fibrillation, etc) and severe aortic diseases (aneurysm, aortic atherosclerosis, etc). ${ }^{2,4}$ It is difficult for AFTs to grow inside the aorta because of the high pressure and fast flow.
AFT without any other severe aortic diseases is really rare, and the etiopathogenesis remains enigmatic. A large, multicenter study of 10,671 consecutive autopsies showed the incidence rate of primary AMT was $0.45 \%$, of which $17 \%$ had autopsy evidence of distal embolization and $6 \%$ had major thromboembolic occlusions considered to be related to the cause of death. ${ }^{5}$ AFTs inside aortic stents also are rare: only 1 of 34 patients with stents developed aortic in-stent thrombus in the study of Song and colleagues ${ }^{6}$ during a follow-up from 3 days to 24 months. AFTs easily are missed because of their lower incidence. Because CTA is now used widely, AFTs have been detected incidentally, which is of important significance to the disease etiology, diagnosis, treatment, and improvement of prognosis.

\section{CTA Findings Analysis and Etiology Exploration of AFT}

Piffaretti and colleagues ${ }^{7}$ reviewed previous reports and found that the most common location of AMTs was the descending aorta $(28 \%)$ or the distal arch $(16 \%)$, with a predilection for the aortic isthmus, whereas the ascending aorta was involved in only $5 \%$ of the cases, which may be attributed to the local special hemodynamic features of the thoracic aorta. In our study, ALFTs were located in the thoracic and upper abdominal aorta. Two lesions were located in the aortic isthmus. One presented in the ascending aorta. These locations are roughly in accordance with previous literature. The morphologies of ALFT were regular with varied sizes. Four lesions were attached to the aortic inner walls by narrow or wide portions with the distal portions free-floating in different lengths, whereas

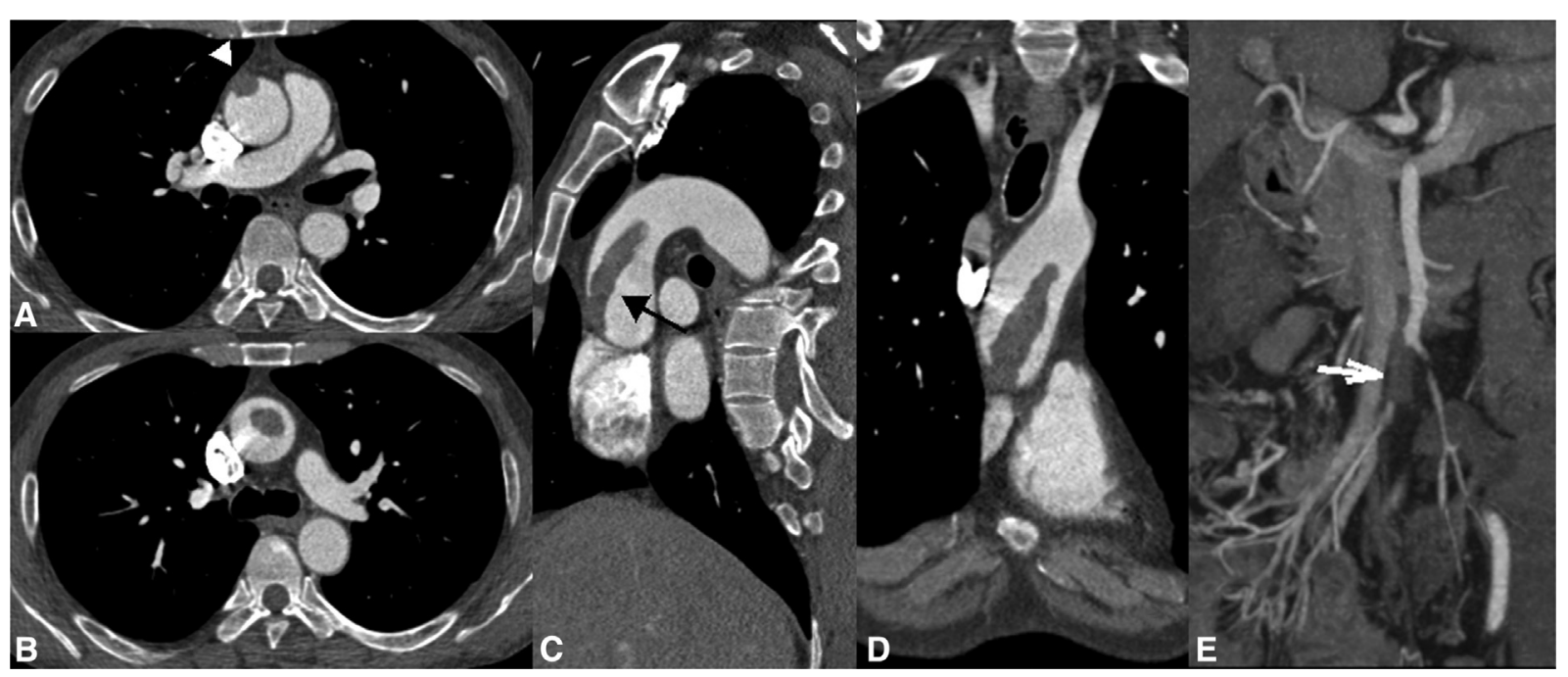

FIGURE 2. CTA-MPR demonstrates a large cylinder-shaped filling defect $(5.6 \times 1.5 \mathrm{~cm})$ attached to the eccentric thickened right anterior wall of aorta (A, white triangle). The lesion grows along with the direction of blood flow (C, D). SMA embolism is shown on MPR image (E, white arrow). 


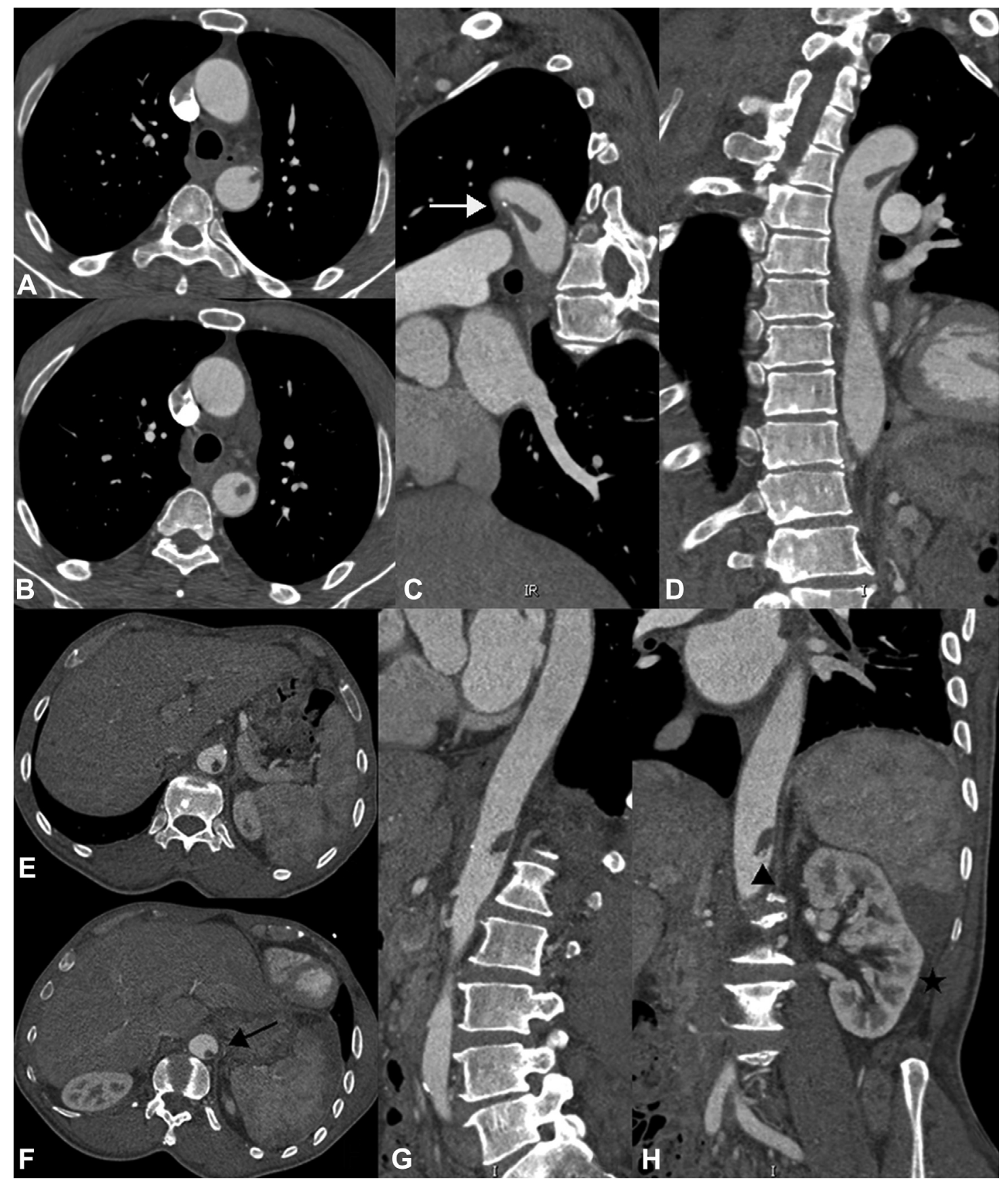

FIGURE 3. CTA-MPR images demonstrate 1 spindle-shaped and 1 bifurcated filling defect $(\mathrm{H}$, black triangle). The involved aortic walls are thickened with/without calcified plaques. (C, white arrow; F, black arrow) The lesions grow along with blood flow (C-D, G-H). Splenic infarction is also noted (H, five-pointed star).

another lesion partial was inserted into the ostium of the intercostal artery.

To describe the hemodynamic features of lesions, we used a new observation parameter, termed boRR, and defined as the length ratio of floating and the attached portion. Theoretically, a greater boRR value has greater potential of breaking off. The lesions' values of boRR reported here ranged from 2.0 to 8.0. Two lesions with boRR of 4.8 and 8.0 broke off during the follow-up, whereas another one with boRR 2.9 was excised by surgery; however, the statistical significance of boRR still requires more cases to verify. Two ALFTs bifurcated distally with small branches, which rarely has been reported. We speculated that this could be regarded as the lesion's partial dissociation with new 


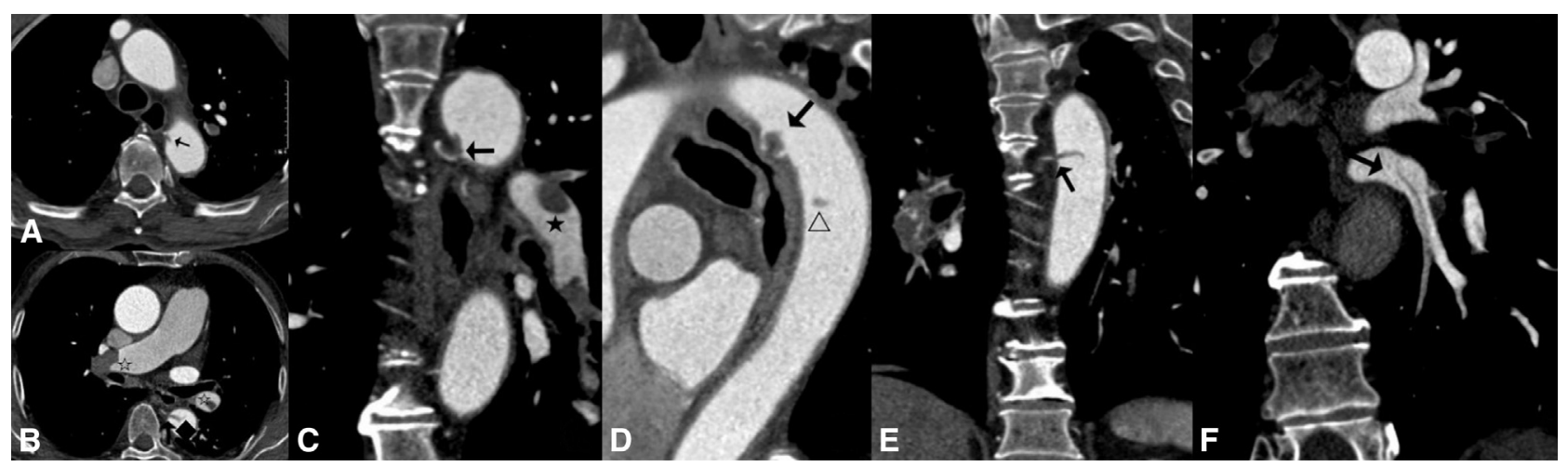

FIGURE 4. CTA-MPR images show 2 stripe filling defects; one lesion bifurcates distally with a small branch (B, black diamond). One ALFT is attached to the focal thickened wall closed to the intercostal artery ostium, which shows like $\mathrm{C}$ type (D, black arrow), whereas the other one partial inserts into the ostium of another intercostal artery (E, black arrow). Thrombi grow perpendicularly to the direction of blood flow. Bilateral pulmonary arteries embolisms and the thrombus in the inferior left pulmonary vein are noted (B-C, five-pointed star; F, black arrow).

growing point, which may be a significant predictor of peripheral embolism. These 2 patients suffered splenic infarction and SMA embolism, respectively.

The etiology of ALFT remains unknown, whereas the possible underlying factors reported previously are mainly vascular endothelial injury, abnormal coagulation function, malignancy, steroids, estrogen, and trauma. ${ }^{4,7-12}$ There are also some cases with rare concomitant disorders that may be the underlying factors of ALFT (Table 3) ${ }^{13-19}$ Some findings on CT may provide clues to explore the cause of lesion. In our study, 4 of 5 ALFTs were attached to the focal thickened walls of aorta with or without calcifications, which suggested the presence of atherosclerotic plaques. All the patients were in hypercoagulation states. One patient's platelet count increased to $954 \times 10^{9} / \mathrm{L}$. Thus, we could speculate that ALFTs are caused by the focal intimal lesions (atherosclerotic plaques) and hypercoagulation states. It is reported widely that ALFTs are associated closely with atherosclerosis, which may be atherosclerotic debris or based on the nidus of atherosclerotic lesions..$^{3,4,7,20-22}$ One ALFT also was attached to the aortic ostium of the intercostal artery and perpendicular to the direction of the blood flow. This special phenomenon may be attributed to the complex hemodynamic change in the bifurcation of the arterial branch. Researchers have found that complex flow phenomenon (flow separation, etc) has an important impact on arterial endothelial injury, intima thickening, and aggregation of platelets, monocytes, and macrophagocytes. ${ }^{23}$ Another ALFT, which was inserted partially into the intercostal artery without involved vessel wall thickening, may have resulted from the upstream lesion taking off and local planting. Regular and follow-up CTA examinations also can detect peripheral thromboembolisms and depict dynamic evolvements of lesions.
In our study, ASFTs were all attached to the focal thickened walls of stents, which may be the result of excessive proliferation of endothelial cells or the mural thrombosis. Three ASFTs were located in the local, abnormal-shaped portions of the stents, where the presence of turbulence, eddy, and other abnormal flow states could impact the wall shear stress on the intima and result in local thrombosis. ${ }^{23}$ The erratic flow distal to the narrowing part of stent strengthens aggregation of lipids, which may result in the thrombosis as well. ${ }^{24}$ Another 3 ASFTs located in the overlaps of the stents may be due to the damaged covers or inadequate endothelialization of the stents as well as irregular anticoagulants. ASFT showed dramatic dynamic changes during the follow-up without obvious peripheral embolisms, which indicates the relative balanced state of the coagulation and dissolution. Previous studies have reported that all lesion relapses involve a different site from the initial one, which suggests diffuse aortic diseases or alterations of the coagulation cascade in these patients and need for long-term anticoagulation therapy and regular clinical examination and imaging. ${ }^{\top}$

\section{Diagnosis and Differential Diagnosis of AFT and Imaging Modality Selection}

The clinical manifestations of AFT are nonspecific. Patients may present clinically with abdominal or chest pains because of the potential visceral infarction. ${ }^{9,22,25}$ In our study, 3 of 5 patients had abdominal pain/discomfort, and another presented with chest pain. Thus, those patients with peripheral embolisms or unexplained chest/ abdominal pains should raise a concern for AFT, especially those with hypercoagulation states and histories of aortic stent implantation. AFT should be differentiated from other aortic diseases such as atherosclerotic plaques and aortic malignancies. Although AFT is associated 

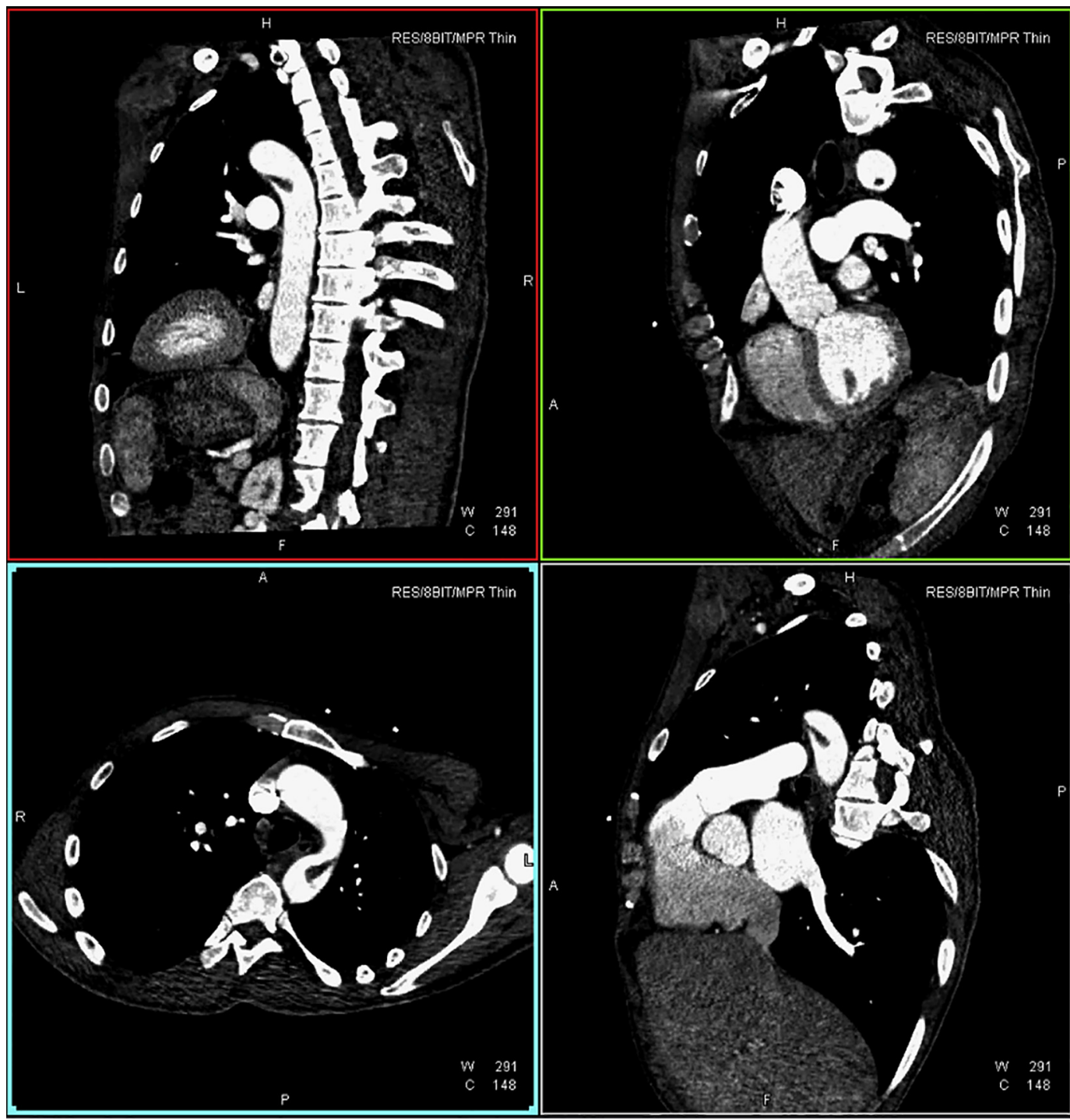

VIDEO 1. CTA-MPR depicts a thoracic aortic floating thrombus floating along with the blood flow in the cardiac cycle. MPR, Multiplanar reconstruction. Video available at: http://www.jtcvsonline.org/article/S0022-5223(16)31805-0/addons.

closely with atherosclerotic plaque in pathogenesis, ${ }^{3,4,20,22}$ the partially dissociated plaque rarely also shows a long, striped lesion with a free portion similar to the findings in our study. Aortic malignancy is even rare and shows a mass-like lesion with nonuniform contrast enhancement on CTA. It is a very life-threatening disease with poor outcomes because the lesion easily breaks off and results in systemic embolism and metastasis, which should be treated by surgery. ${ }^{26-28}$

To make a general diagnosis of AFT, routine laboratory tests, including complete hematologic testing, are crucial to identify the etiology. ${ }^{15}$ With the rapid development in CT technology, greater spatial and temporal resolution with lower radiation and powerful postprocessing techniques are now able to demonstrate lesions inside the aortic lumens/stents clearly and tridimensionally. The involved aorta, stents, and concomitant body embolisms also can be detected by CTA at the same time. Cine-CT can depict the motion of thrombus dynamically, although it is reported rarely. CTA scanning has been the routine examination of choice for AFT, whereas special imaging findings may be vital predictors to the lesion's etiology and break-off potential. $^{6,7}$

All the lesions in our study were detected by CTA examination. Nevertheless, there are some disadvantages of CTA, such as radiation and potential iodine-anaphylaxis. 


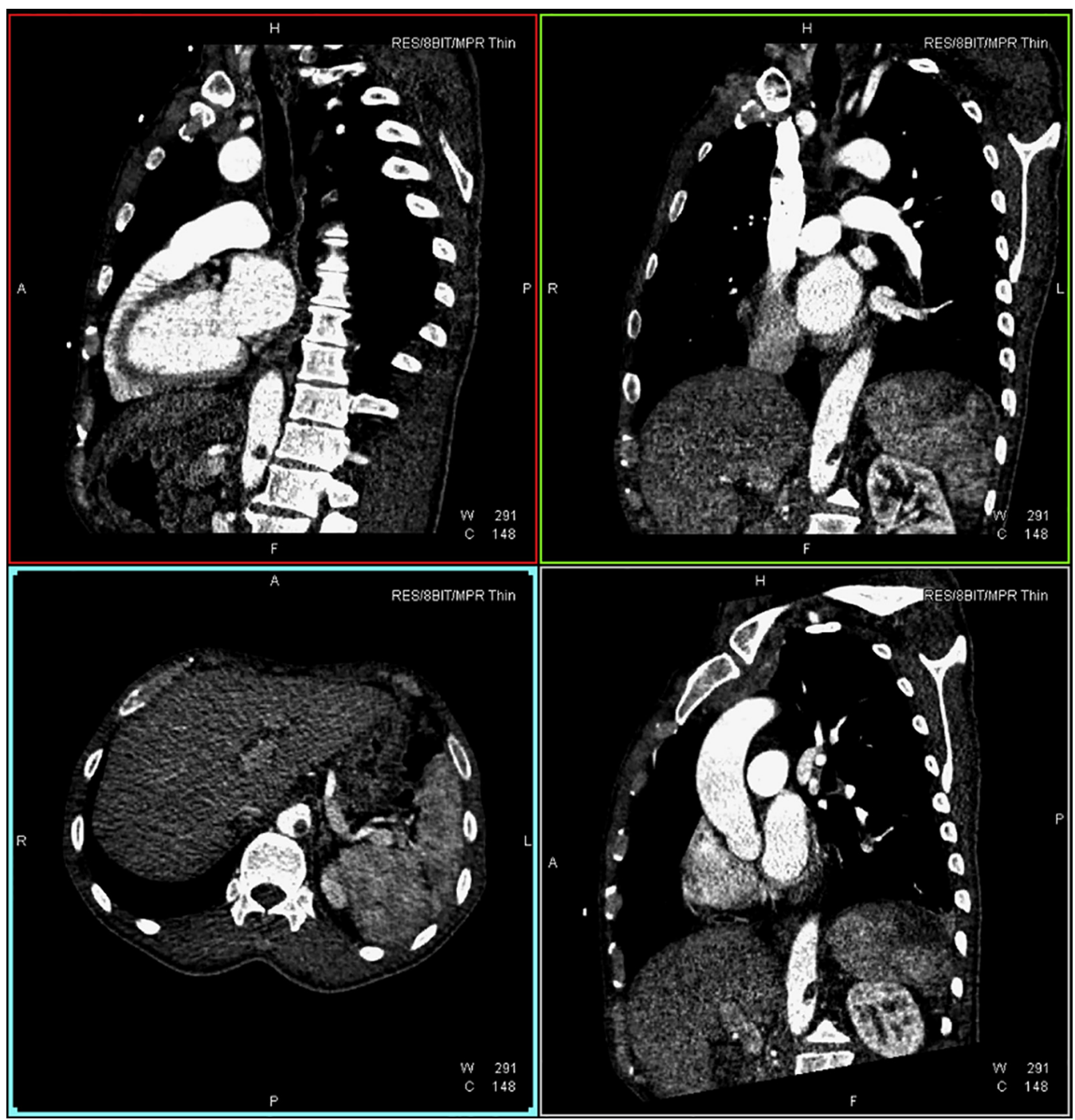

VIDEO 2. CTA-MPR depicts an abdominal aortic floating thrombus floating along with the blood flow in the cardiac cycle. $M P R$, Multiplanar reconstruction. Video available at: http://www.jtcvsonline.org/article/S0022-5223(16)31805-0/addons.

Transesophageal echocardiography (TEE) is used widely all over the world and can detect the lesion dynamically whereas cardiac diseases also can be revealed at the same time with greater sensitivity and accuracy. Some AFTs reported previously also were detected by $\mathrm{TEE}^{19-22}$; however, some parts of the aorta, such as the ascending aorta and upper descending aorta, are partially apart from the trachea, which cannot be detected clearly by TEE and thus result in a missed diagnosis. Magnetic resonance imaging also is used widely because of its specific advantages. The high tissue resolution contributes to the differential diagnosis from aortic malignancy, and the additional use of cine-magnetic resonance imaging can evaluate hemodynamic features of lesions. ${ }^{7,25}$ Digital subtraction angiography is an invasive method and only preserved for interventional therapy.

\section{Management and Prognosis of AFT}

AFTs can easily break off and result in peripheral embolism, which negatively affects the patient's prognosis. The most likely suffered arteries are the lower extremities arteries, followed by the SMA and renal artery. The involvements of splenic artery, upper extremities arteries, cerebral artery, and coronary artery are rare but have worse prognoses. ${ }^{1,7,15,29-33}$ Once the diagnosis of AFT is established, reasonable and individualized treatment should be undertaken as soon as possible. 


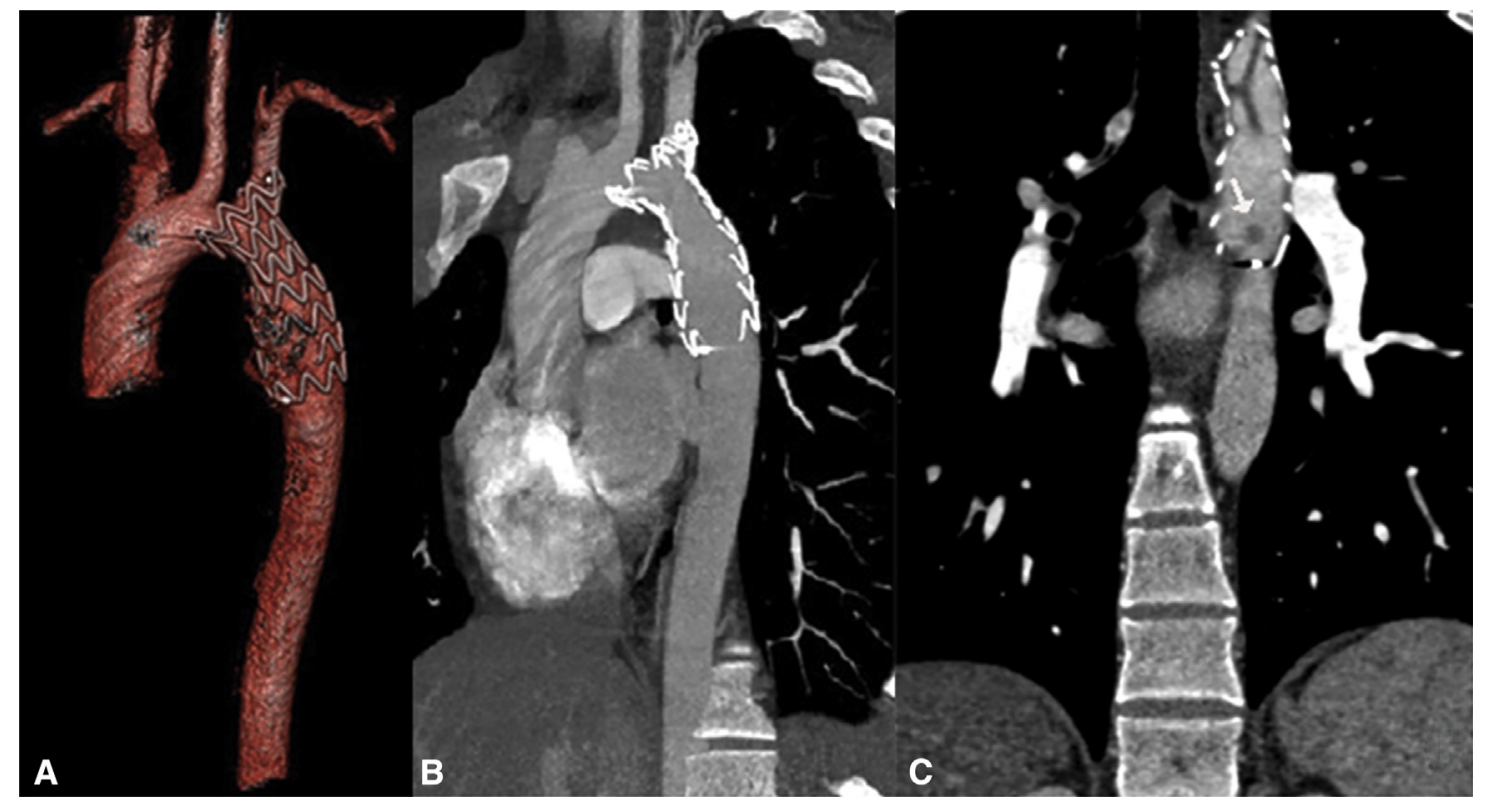

FIGURE 5. CTA-VRT image (A) shows a thoracic aortic stent within the descending thoracic aorta. There is a small gap between the proximal uncovered portion and the inferior wall of aortic arch. The superior part of the proximal uncovered portion inserts into proximal LSCA. Overexpansion of distal stent is noted (A, B). CTA-MPR images (C) show 2 AFT within the thoracic aortic stent, of which one is irregular and flaky with multiple attachments and another is linear-shaped (white arrow) (C).

Because of the paucity of reported cases, there is no standardized therapeutic protocol and clinical guideline of this condition. The therapeutic options are really based on the patients' conditions and doctors' experience. The therapies with varying levels of invasiveness and effectiveness mainly include conservative treatment (anticoagulant and thrombolytic drugs), interventional treatment (thromboaspiration, endovascular graft exclusion, ballooncatheter thrombectomy and transfemoral thrombectomy), and open surgery (thrombectomy, thromboendarterectomy and aortic replacement). ${ }^{7,25}$ A number of studies now demonstrate conservative treatment, ie, medication, to be effective, which is recommended as the first choice, especially for asymptomatic patients with a high risk of peripheral embolism and relapse. Interventional endovascular thrombectomy has less risk than open surgery, but it is easy to crash the thrombus and lead to peripheral embolism during the operation, whereas a filter screen distal to the lesion may have a preventative effect.

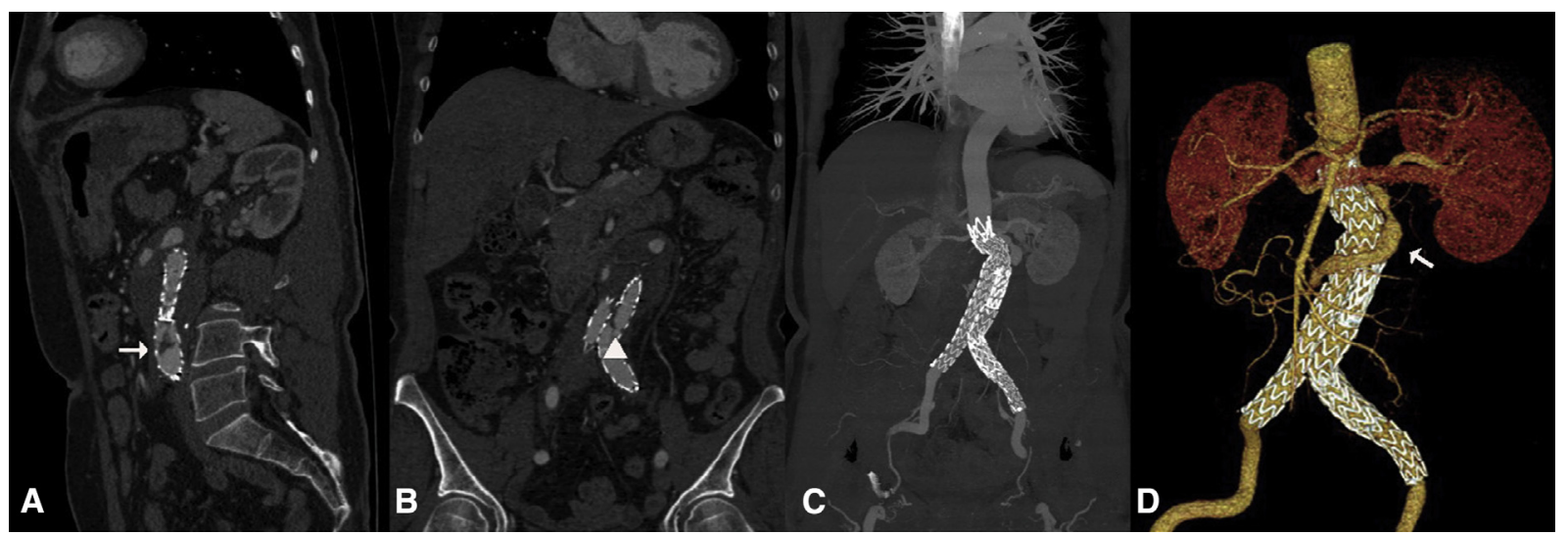

FIGURE 6. CTA-MPR images show an irregular and flaky filling defect in the overlapped portion of the aortoilliac stents with multiple attachments (A, white arrow). MIP image shows kinking of the proximal herringbone stent (C). CTA-VRT image shows type II internal leakage inferior to left renal artery $(\mathrm{D}$, white arrow). 


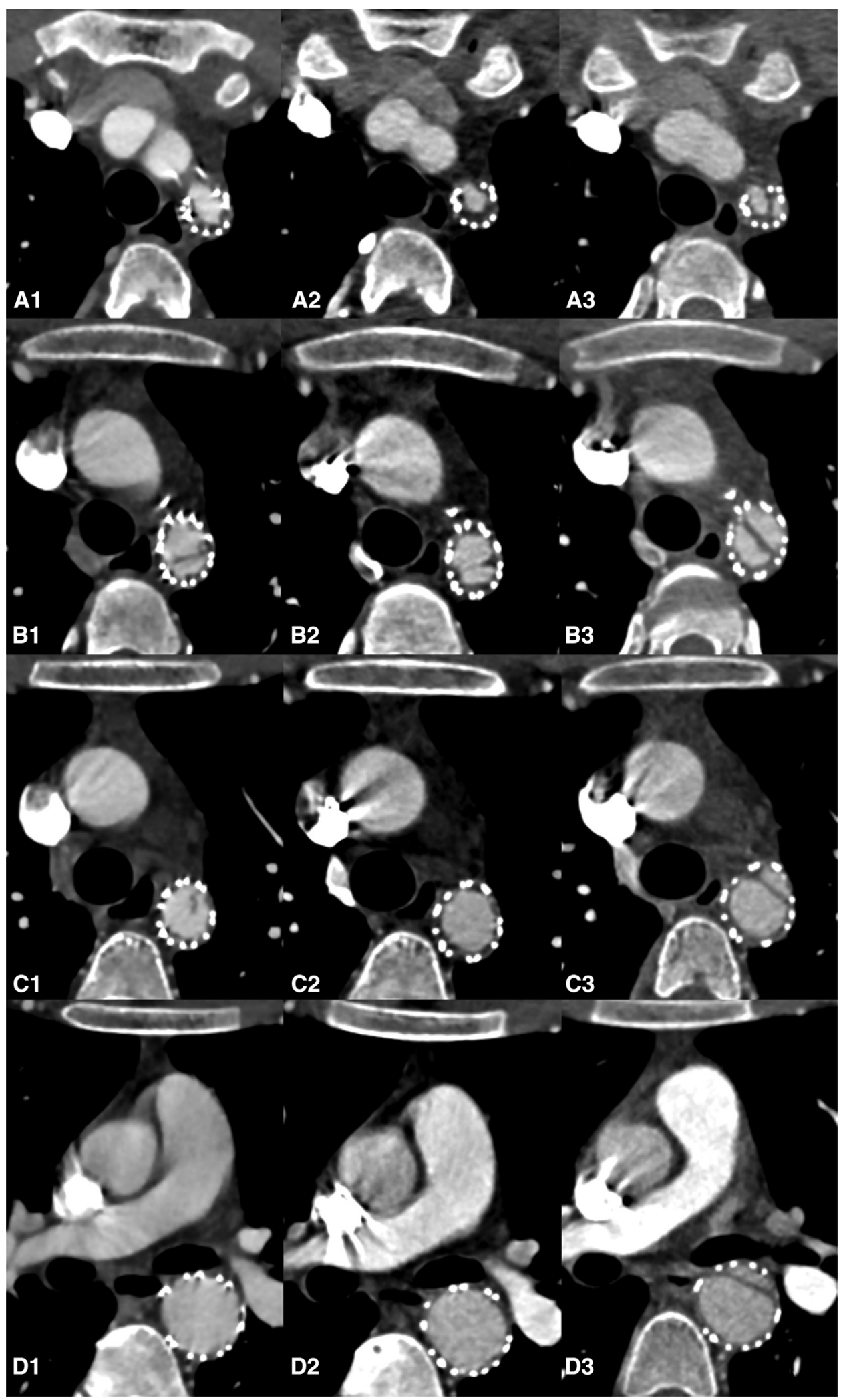

FIGURE 7. CTA images show varied appearance of the thrombi during the follow-up period in patient 4 (1-3) while the stents nonuniform expand (B1-3, C1-3) and the inwalls thicken especially in proximal LSCA (A1-3). The wire-shaped thrombus showed 2 attachment points adhering to the aortic stent wall, respectively (D3). 
TABLE 2. Imaging findings of the 5 patients with aortic floating thrombus in our report

\begin{tabular}{|c|c|c|c|c|c|c|c|c|c|}
\hline Patient & $\begin{array}{l}\text { Number } \\
\text { of lesions }\end{array}$ & Location & \multicolumn{2}{|c|}{ Morphology/boRR } & \multicolumn{2}{|c|}{ Involved aorta } & $\begin{array}{l}\text { Mobilization } \\
\text { dynamics }\end{array}$ & $\begin{array}{c}\text { Concomitant } \\
\text { embolism }\end{array}$ & $\begin{array}{c}\text { Follow-up } \\
\text { (times/interval } \\
\text { time/period) }\end{array}$ \\
\hline 1 (Figure 2) & 1 & Ascending aorta & Cylinder $(5.6 \times 1.5$ & $5 \mathrm{~cm}) / 2.9$ & $\begin{array}{l}\text { Focal eccentric thicke } \\
\text { of the aorta }\end{array}$ & ned wall & $\begin{array}{l}\text { Along with the } \\
\text { direction of } \\
\text { the blood } \\
\text { flow }\end{array}$ & $\begin{array}{l}\text { SMA } \\
\text { embolism }\end{array}$ & $\begin{array}{l}\text { Original lesion } \\
\quad \text { disappeared, } \\
\text { aortic } \\
\text { postoperative } \\
\text { change, without } \\
\text { new-onset } \\
\text { embolism. } \\
(1 / 21 \mathrm{mo} / 65 \mathrm{mo})\end{array}$ \\
\hline 2 (Figure 3) & 2 & $\begin{array}{cl}\text { Aortic } & \text { Upper } \\
\text { isthmus } & \text { abdominal } \\
& \text { aorta } \\
& \text { superior } \\
& \text { to the celiac } \\
& \text { trunk }\end{array}$ & $\begin{array}{l}\text { Spindle-shaped } \\
\quad(0.9 \times 0.7 \times \\
2.2 \mathrm{~cm}) / 4.8\end{array}$ & $\begin{array}{l}\text { Cylinder- } \\
\text { shaped with } \\
\text { a small } \\
\text { branch distal } \\
\text { to the lesion } \\
(0.8 \times \\
1.8 \mathrm{~cm}) / 8.0\end{array}$ & $\begin{array}{l}\text { Focal thickening } \\
\text { with a point-like } \\
\text { calcified plaque }\end{array}$ & $\begin{array}{l}\text { Focal } \\
\quad \text { thickening } \\
\text { without } \\
\text { calcified } \\
\text { plaque }\end{array}$ & $\begin{array}{l}\text { Along with the } \\
\text { direction of } \\
\text { the blood } \\
\text { flow }\end{array}$ & $\begin{array}{l}\text { Splenic } \\
\quad \text { infarction }\end{array}$ & $\begin{array}{l}\text { Original lesions } \\
\text { disappeared, } \\
\text { splenic infarction } \\
\text { enlargement with } \\
\text { new-onset left } \\
\text { renal infarction } \\
(1 / 7 \mathrm{~d} / 14 \mathrm{mo})\end{array}$ \\
\hline 3 (Figure 4) & 2 & $\begin{array}{cc}\text { Aortic } & \text { Thoracic } \\
\text { isthmus } & \text { aorta }\end{array}$ & $\begin{array}{l}\text { Short, striped in } \\
\text { appearance and } \\
\text { easily } \\
\text { overlooked } \\
(0.1 \times \\
0.4 \mathrm{~cm}) / 2.0\end{array}$ & $\begin{array}{l}\text { Striped in } \\
\text { appearance } \\
\text { with a small } \\
\text { branch distal } \\
\text { to the lesion } \\
(0.3 \times \\
1.6 \mathrm{~cm}) /-\end{array}$ & $\begin{array}{l}\text { The focal thickened } \\
\text { wall of aorta close } \\
\text { to the ostium of } \\
\text { intercostal artery }\end{array}$ & $\begin{array}{l}\text { The ostium } \\
\text { of intercostal } \\
\text { artery }\end{array}$ & $\begin{array}{l}\text { Perpendicular } \\
\text { to the } \\
\text { direction } \\
\text { of the blood } \\
\text { flow }\end{array}$ & $\begin{array}{l}\text { Pulmonary } \\
\text { infarction, } \\
\text { line-like } \\
\text { thrombus } \\
\text { in bilateral } \\
\text { pulmonary } \\
\text { veins and } \\
\text { SMA }\end{array}$ & - \\
\hline $\begin{array}{l}4 \\
\text { (Figures } \\
5 \text { and } 7 \text { ) }\end{array}$ & 1 & $\begin{array}{l}\text { Thoracic aortic stent } \\
\text { (original coarctation } \\
\text { part of the stent) }\end{array}$ & $\begin{array}{l}\text { Irregular, flaky } \\
\text { filling defects, } m \\
\text { attachments to th } \\
\text { wall with the me } \\
\text { free-floating }\end{array}$ & $\begin{array}{l}\text { nultiple } \\
\text { he stent inner } \\
\text { edian portion }\end{array}$ & $\begin{array}{l}\text { A gap between proxin } \\
\text { the thoracic aortic } \\
\text { aortic wall. The ste } \\
\text { inserted partially in } \\
\text { left subclavian arte } \\
\text { distal stent was mil }\end{array}$ & $\begin{array}{l}\text { nal end of } \\
\text { stent and the } \\
\text { ent was } \\
\text { to proximal } \\
\text { ry, whereas the } \\
\text { ldly expanded }\end{array}$ & $\begin{array}{l}\text { Median partial } \\
\text { component } \\
\text { floating } \\
\text { along } \\
\text { with the } \\
\text { blood flow }\end{array}$ & - & $\begin{array}{l}\text { Original lesion } \\
\text { varied with } \\
\text { new wire-shaped } \\
\text { lesion in the } \\
\text { focal expansion } \\
\text { of distal stent } \\
\text { without any } \\
\text { peripheral } \\
\text { embolism } \\
\text { (2/6 mo-14 mo/ } \\
28 \mathrm{mo})\end{array}$ \\
\hline 5 (Figure 6) & 1 & $\begin{array}{l}\text { Junction of stent body } \\
\text { and iliac limbs }\end{array}$ & $\begin{array}{l}\text { Irregular, flaky fillir } \\
\text { defects }\end{array}$ & & $\begin{array}{l}\text { Tortuosity with type II } \\
\text { leakage }\end{array}$ & I internal & $\begin{array}{l}\text { Mainly stable } \\
\text { state } \\
\text { with partial } \\
\text { components } \\
\text { floating }\end{array}$ & - & $\begin{array}{l}\text { Original thrombus } \\
\text { dissolved with } \\
4 \text { new thrombi } \\
\text { without any } \\
\text { peripheral } \\
\text { embolism } \\
(2 / 19 \mathrm{mo}-22 \\
\text { mo/41 mo) }\end{array}$ \\
\hline
\end{tabular}

boRR, Break-off risk ratio; SMA, superior mesenteric artery.

Aortic endovascular graft exclusion is a new developed therapy with good therapeutic effect. It is especially suitable to the poor general body state of patients with ineffective courses of medication; however, it also may have the potential to relapse, whereas the long-term effect remains unknown. Open surgery is being replaced gradually by other therapeutic methods because of high inherent risk and complications. Surgery, however, should be considered initially if the lesion is suspected preoperatively to be malignant, with high possibility of dislodgement or frequent relapse, whereas the pathology finding of the lesion is the gold standard of diagnosis and guides therapy. ${ }^{7,15,22,25,31,34}$ Long-term, individualized posttherapy treatment also makes significant sense to improve a patient's prognosis.

In our study, only one patient underwent ascending thrombectomy and aortic graft replacement with regular postoperative anticoagulant for the preoperative suspicion for malignancy. CTA examination during follow-up revealed no new relapses or peripheral embolisms. There were 2 patients treated conservatively (medication). In one, follow-up CTA showed resolution of the lesions with enlarged splenic infarction and new left renal segmental infarction. The symptom of the other patient was relieved after anticoagulation therapy without follow-up CTA. In the 2 patients with stents (one of 
TABLE 3. Previous reports of aortic floating thrombus with special disorders

\begin{tabular}{|c|c|c|c|c|c|c|c|}
\hline Author & Age, $y / \operatorname{sex}$ & Symptom & Location & $\begin{array}{c}\text { Lesion } \\
\text { number/size }\end{array}$ & $\begin{array}{l}\text { Other aortic } \\
\text { disease }\end{array}$ & $\begin{array}{c}\text { Contemporary } \\
\text { disorders }\end{array}$ & $\begin{array}{c}\text { Management/ } \\
\text { pathology }\end{array}$ \\
\hline $\begin{array}{l}\text { Fagnoul and } \\
\text { colleagues }^{13}\end{array}$ & $92 \mathrm{y} / \mathrm{male}$ & Cardiac arrest & Descending aorta & $1 /-$ & Hematoma & $\begin{array}{l}\text { Post-CPR due to } \\
\text { the cardiac arrest, } \\
\text { aortic compression } \\
\text { during CPR }\end{array}$ & $\begin{array}{l}\text { Anticoagulation } \\
\text { therapy }\end{array}$ \\
\hline $\begin{array}{l}\text { Alla and } \\
\text { colleagues }^{14}\end{array}$ & $45 \mathrm{y} /$ female & Cardiac arrest & $\begin{array}{l}\text { Descending thoracic } \\
\text { aorta (the aortic isthmus) }\end{array}$ & $1 / 4.6 \mathrm{~cm}$ in length & - & $\begin{array}{l}\text { Methamphetamine } \\
\text { user }\end{array}$ & $\begin{array}{l}\text { Stent-graft and } \\
\text { anticoagulation } \\
\text { therapy }\end{array}$ \\
\hline $\begin{array}{l}\text { Lee and } \\
\qquad \text { colleagues }^{15}\end{array}$ & $67 \mathrm{y} / \mathrm{female}$ & $\begin{array}{l}\text { Cerebral } \\
\text { infarction, }\end{array}$ & Ascending aorta & $1 / 2.5 \mathrm{~cm}$ in length & $\begin{array}{l}\text { Vessel damage } \\
\text { due to systemic } \\
\text { sclerosis }\end{array}$ & $\begin{array}{l}\text { Long-term use of } \\
\text { steroids }\end{array}$ & $\begin{array}{l}\text { Surgery (lesion } \\
\text { excision)/thrombus }\end{array}$ \\
\hline $\begin{array}{l}\text { Rafiq and } \\
\text { colleagues }^{16}\end{array}$ & $59 \mathrm{y} /$ female & - & $\begin{array}{l}\text { Distal aortic arch } \\
\text { (above the remnant } \\
\text { of the arterial duct) }\end{array}$ & $\begin{array}{l}1 / 4 \mathrm{~cm} \times \\
1 \mathrm{~cm} \times 0.8 \mathrm{~cm}\end{array}$ & - & $\begin{array}{l}\text { Postsplenectomy } \\
\text { for B-cell } \\
\text { lymphoma }\end{array}$ & $\begin{array}{l}\text { Surgery (lesion } \\
\text { excision)/pale } \\
\text { hemorrhagic } \\
\text { tissue fibrin } \\
\text { thrombus with } \\
\text { a few atypical } \\
\text { lymphoid cells }\end{array}$ \\
\hline $\begin{array}{l}\text { Yoon and } \\
\text { colleagues }^{17}\end{array}$ & $57 \mathrm{y} / \mathrm{male}$ & Ischemic left foot & Descending aorta & $1 / 2.8 \mathrm{~cm} \times 0.9 \mathrm{~cm}$ & - & $\begin{array}{l}\text { Postrectal amputation } \\
\text { due to distal } \\
\text { rectum cancer, } \\
\text { chemotherapy } \\
\text { using bevacizumab } \\
\text { with IFL }\end{array}$ & $\begin{array}{c}\text { Chemotherapy drug } \\
\text { dose adjusted }\end{array}$ \\
\hline $\begin{array}{l}\text { Apiyasawat } \\
\text { and colleagues }\end{array}$ & $59 \mathrm{y} /$ female & Right leg embolism & Aortic arch & $\begin{array}{l}\text { 1/attachment: } \\
2.5 \mathrm{~cm} \times 1.2 \mathrm{~cm}, \\
\text { floating portion: } \\
1.7 \mathrm{~cm} \times 0.7 \mathrm{~cm}\end{array}$ & - & $\begin{array}{l}\text { Platinum } \\
\text { chemotherapy } \\
\text { due to cervical } \\
\text { carcinoma }\end{array}$ & $\begin{array}{l}\text { Surgery (lesion } \\
\text { excision)/thrombus }\end{array}$ \\
\hline $\begin{array}{l}\text { Grothues and } \\
\text { colleagues }^{19}\end{array}$ & $49 \mathrm{y} / \mathrm{male}$ & $\begin{array}{l}\text { Recurrent } \\
\text { thromboembolism }\end{array}$ & Aortic arch & $1 / 4 \mathrm{~cm}$ in length & - & $\begin{array}{l}\text { Systemic fungal } \\
\text { infection }\end{array}$ & $\begin{array}{l}\text { Antibiotic treatment, } \\
\text { autopsy/thrombus } \\
\text { caused by } \\
\text { aspergillus invasion }\end{array}$ \\
\hline
\end{tabular}

$C P R$, Cardiopulmonary resuscitation; $I F L$, irinotecan, fluorouracil, and leucoverin.

them took anticoagulants regularly after operation), follow-up CTA demonstrated the lesions had varied in morphology and locations without any new-onset peripheral embolisms, indicated with a high risk of peripheral embolism.

\section{CONCLUSIONS}

AFT is a rare but significant source of peripheral embolism that should attract the attention of clinicians and radiologists. Abnormal coagulation function, aortic diseases (including abnormal aortic morphology), and a history of aortic stent implantations (especially with abnormal shape of stents) are potential predictors of AFT. The symptoms of the disease are nonspecific. Unexplained chest and abdominal pain should alert the clinicians to order a thorough workup, including hematologic tests, and imaging examination should be implemented at the first instance. CTA scanning is recommended as a first-choice examination because of advantages such as convenience and high sensitivity. Management includes conservative treatment (medication), intraluminal treatment, and open surgery, whereas the selection is based on the etiology as well as the patients' physical conditions. Conservative treatment (medication) is recommended as the first choice, although there is a high risk of peripheral embolisms and relapse. Long-term individualized therapy and follow-up is vital to improve patient's prognosis.

\section{Conflicts of Interest Statement}

Authors have nothing to disclose with regard to commercial support.

We would like to express our gratitude to Dr Hanping Wu, radiology resident, Department of Radiology at University Hospitals Case Medical Center, Cleveland, Ohio, who helped us during the writing of the paper.

\section{References}

1. Bowdish ME, Weaver FA, Liebman HA, Rowe VL, Hood DB. Anticoagulation is an effective treatment for aortic mural thrombi. J Vasc Surg. 2002;36:713-9.

2. Tsilimparis N, Hanack U, Pisimisis G, Yousefi S, Wintzer C, Rückert RI. Thrombus in the non-aneurysmal, non-atherosclerotic descending thoracic 
aorta-an unusual source of arterial embolism. Eur J Vasc Endovasc Surg. 2011; 41:450-7.

3. Karalis DG, Chandrasekaran K, Victor MF, Ross JJ Jr, Mintz GS. Recognition and embolic potential of intraaortic atherosclerotic debris. J Am Coll Cardiol. 1991; 17:73-8.

4. O'Connell JB, Quiñones-Baldrich WJ. Proper evaluation and management of acute embolic versus thrombotic limb ischemia. Semin Vasc Surg. 2009;22:10-6.

5. Machleder HI, Takiff H, Lois JF, Holburt E. Aortic mural thrombus: an occult source of arterial thromboembolism. J Vasc Surg. 1986;4:473-8.

6. Song YL, Wang D, Zhang WS, Fang H, Zhu HX, Meng LM, et al. Evaluation of spiral CT angiography in post operative follows up of endoluminal stent grafting with aortic disease (in Chinese). Chin J Interv Imaging Ther. 2007;4:106-9.

7. Piffaretti G, Tozzi M, Mariscalco G, Bacuzzi A, Lomazzi C, Rivolta N, et al. Mobile thrombus of the thoracic aorta: management and treatment review. Vasc Endovascular Surg. 2008;42:405-11.

8. Bosma J, Rijbroek A, Rauwerda JA. A rare case of thromboembolism in a 21-year old female with elevated factor VIII. Eur J Vasc Endovasc Surg. 2007;34:592-4.

9. Hazirolan T, Perler BA, Bluemke DA. Floating thoracic aortic thrombus in "protein S" deficient patient. J Vasc Surg. 2004;40:381.

10. Choi JB, Choi SH, Kim NH, Jeong JW. Floating thrombus in the proximal aortic arch. Tex Heart Inst J. 2004;31:432-4.

11. Cogert G, Siegel RJ. Giant floating aortic thrombus: a rare finding on transesophageal echocardiography. Am J Cardiol. 2007;99:739-40.

12. Lopez S, Tarmiz A, Rousseau H, Fournial G. Floating aortic thrombus: aortic trauma treated by heparin and delayed covered stent. Ann Vasc Surg. 2011;25:984.e1-3.

13. Fagnoul D, Herpain A, Vincent JL, De Backer D. Aortic luminal thrombus and intramural hematoma after cardiopulmonary resuscitation. Rev Bras Ter Intensiva. 2013;25:345-7.

14. Alla VM, Thota R, Mathias S, Holmberg M, Hunter C. Mobile thoracic aortic thrombus in a methamphetamine user after cardiac arrest. Tex Heart Inst J. 2011;38:445-7.

15. Lee S, Cho JW, Kwon OC. Floating thrombus in the ascending aorta of the patient with systemic sclerosis - a case report. Korean J Thorac Cardiovasc Surg. 2011; 44:72-5.

16. Rafiq MU, Jajja MM, Qadri SS, Robinson GJ, Cale AR. An unusual presentation of pedunculated thrombus in the distal arch of the aorta after splenectomy for B-cell lymphoma. J Vasc Surg. 2008;48:1603-4.

17. Yoon S, Schmassmann-Suhijar D, Zuber M, Konietzny P, Schmassmann A. Chemotherapy with bevacizumab, irinotecan, 5-fluorouracil and leucovorin (IFL) associated with a large, embolizing thrombus in the thoracic aorta. Ann Oncol. 2006;17:1851-2.

18. Apiyasawat S, Wongpraparut N, Jacobson L, Berkowitz H, Jacobs LE, Kotler MN. Cisplatin induced localized aortic thrombus. Echocardiography. 2003;20:199-200.

19. Grothues F, Welte T, Grote HJ, Roessner A, Klein HU. Floating aortic thrombus in systemic aspergillosis and detection by transesophageal echocardiography. Crit Care Med. 2002;30:2355-8.
20. Kalangos A, Baldovinos A, Vuille C, Montessuit M, Faidutti B. Floating thrombus in the ascending aorta: a rare cause of peripheral emboli. J Vasc Surg. 1997;26:150-4.

21. Laperche T, Laurian C, Roudaut R, Steg PG. Mobile thromboses of the aortic arch without aortic debris. A transesophageal echocardiographic finding associated with unexplained arterial embolism. The Filiale Echocardiographie de la Société Française de Cardiologie. Circulation. 1997;96:288-94.

22. Gouëffic Y, Chaillou P, Pillet JC, Duveau D, Patra P. Surgical treatment of nonaneurysmal aortic arch lesions in patients with systemic embolization. J Vasc Surg. 2002;36:1186-93.

23. Bai F, Liu YJ, Xie JS, Ding JL, Wang F, Zhao X, et al. Recent development and application of hemodynamics (in Chinese). J Med Biomech. 2013;28:677-83.

24. Deng XY, Fatouraee N, Guidoin R. Numerical simulation of low density lipoprotein $(L D L)$ transport in arterial stenosis. Proceedings of the IASTED International Conference on Biomechanics. Calgary: ACTA Press; 2004. 94-6.

25. Scott DJ, White JM, Arthurs ZM. Endovascular management of a mobile thoracic aortic thrombus following recurrent distal thromboembolism: a case report and literature review. Vasc Endovascular Surg. 2014;48:246-50.

26. Mecklai A, Rosenzweig B, Applebaum R, Axel L, Grossi E, Chan A, et al. Intimal sarcoma in the aortic arch partially obstructing the aorta with metastasis to the brain. Tex Heart Inst J. 2014;41:433-6.

27. Thalheimer A, Fein M, Geissinger E, Franke S. Intimal angiosarcoma of the aorta: report of a case and review of the literature. J Vasc Surg. 2004;40 548-53.

28. Salhab KF, Said SM, Sundt TM III. Pseudocoarctation of the aorta secondary to aortic intimal sarcoma. Ann Thorac Surg. 2012;94:279-81.

29. Dhillon P, Murdoch D, Jayasinghe R, Niranjan S. A case of mobile aortic arch thrombus with systemic embolisation-a management dilemma. Heart Lung Circ. 2014;23:e88-91.

30. Noh TO, Seo PW. Floating thrombus in aortic arch. Korean J Thorac Cardiovase Surg. 2013;46:464-6.

31. Sawada T, Shimokawa T. Giant thrombus in the ascending aorta that caused systemic embolism. Interact Cardiovasc Thorac Surg. 2011;12:1048-50.

32. Hisatomi K, Yamada T, Odate T, Yamashita K. Intermittent coronary artery occlusion caused by a floating thrombus in the left coronary sinus of Valsalva of a patient with a normal aorta and protein C deficiency. Ann Thorac Surg. 2011;92:1508-10.

33. Nakamura D, Makino N, Egami Y, Shutta R, Tanouchi J, Nishino M. Successful thrombectomy for coronary embolism likely due to floating aortic plaque in ascending aorta. Cardiovasc Interv Ther. 2015;30:299-302.

34. Fukuhara S, Tyagi S, Clarke-Pearson E, Bernik T. Endovascular stent graft repair of thoracic aortic mural thrombus in a patient with polycythemia vera: a word of caution. Vascular. 2015;23:89-92.

Key Words: floating thrombus, embolism, hypercoagulation, aortic stent, computed tomography angiography 